\title{
Fostering Social Caring Through Multicultural-Based
}

\section{Language Learning}

\author{
M. TolkhahAdityas
}

Ahmad Dahlan University, Yogyakarta

\begin{abstract}
Social caring can be interpreted as affection and attention to other people which can later be manifested in an appreciating, accepting, and helping behavior. The behavior is not automatically possessed by each individual. Instead, it should be learnt, understood, internalized, and implemented in daily life. This article aims at discussing the strategies to enhance students social caring through multicultural awareness in language learning. Social caring serves as character values which appreciates diversity. It needs to be internalized from the very early age so that each individual understands how to deal with diversity. One of the alternatives in supporting the implementation of social care character is through multicultural-based learning activities. Hopefully, this type of learning leads students to appreciate diversity.
\end{abstract}

Keywords: character, social caring, multicultural-based activities

\section{INTRODUCTION}

Degradation of human character gradually increasesamong Indonesian society. Various media frequentlybroadcast news about immoral acts involving state officiers, communities, and even school students. Cases such as corruption,free sex, murder, and rape seem to be happening more often. The rise of these immoral acts is very alarming and shows the problems of education system in Indonesia. Education determines the development of a nation. Therefore, it is expected to produce qualified and fully developed humans who can play active roles in building the nation.

There are three functions of national education. The first is developing students' ability. This means that learners have enormous potential so that education in Indonesia should be able to facilitate ability to develop optimally. The second is forming character. It means that the implementation of national education should be directed to shape learners' character. The third is nation civilization, which implies that in order to build a civilized nation, Indonesia needs educated human beings, and it certainly requires a very long time.

Education should be able to both form intelligent people and develop students' characters. Education today is seen to have meaning shift, leading to the concept which glorifies score. MasnurMuslich (2011: 17) says that current education emphasizes too much on the cognitive aspect, and is less able to develop values, attitudes, and character. In learning process, values are unfortunately taught separately.

Various examples of immoral acts indicates that we need strong foundation which is called character. Considering the importance of character to build the personality of a person and nation, educators offer a variety of solutions, one of which is character education. The main goal of character education is to strengthen and develop values which will be manifestedin students' behaviour.

Mohammad Nuh in Swarapendidikan.com (May 5, 2011) in his speech when National Education Day says character education is very important in schools. There are two things that can be done in school to form a good character. First, internalizing character education from early age.Second, integrating noble values in all subjects such as Mathematics, Social, Science, Language, and Arts. The statement implies that the school is a strategic place and has a big role to build a person's character.

\section{RESULTS AND ANALYSIS}

\section{Character Education}

Education is a conscious effort undertaken by a person or a teacher to develop other people or learners'personality. Therefore, education becomes an appropriate instrument to instill and develop character. This is in line with the opinion of Martin Luther King (Berkowitz \& Simmons, 2003: 118) "Intelligence is not enough. Intelligence plus character is the goal of true education" 
According to Dharma Kesuma, Cepi Triatna, \& Johar Permana (2011: 5) character education in schools leads to the strengthening and developing children's behavior based on noble values. This definition implies that 1) character education is an integrated education in learning that occurs in all subjects, 2) character education is directed to strengthen and develop students' behavior, 3 ) the developing of behavior is based on the values referred by the school.

Lickona (1991: 53) explains components of good character consist of moral knowing, moral feeling, and moral action". Aspects included in moral knowing are moral awareness, knowingmoral values, perspective taking, moral reasoning, decision making and self-recognition. Moral feeling is a feeling about morals, strengthening the emotional aspects of students to become humanswith character. The strengthening is related to the forms of attitudes that must be perceived by the students, namely conscience, self esteem, empathy, loving the good, self control, and humility. While moral action is moral that resultsfrom the two other character components. In addition, Battistich (2008: 82) explains "character education as deliberate use of all dimensions of school life to foster optimal character development". Character education can be realized by involving all existing components in the school such as curriculum, learning process, relationship quality, subject management, co-curricular activities, and school environment.

Character education is a genuine effort, leading to the strengthening and developing of students' knowledge, awareness, and behavior based on certain values in the environment. The purpose of character education is to establish good students. Once a student is grown in good character, he or she will grow up with the commitment to do the best things, do the right things, and have a purpose in life.

\section{Strategy and Development of Character Education}

Ministry ofEducation (2010: 12-20), explains that the development of national character and culture can be achieved through three ways: 1) through all subjects, 2) throughpersonal-development, and 3) through school culture. The strategy of character education is described as in Figure 1.

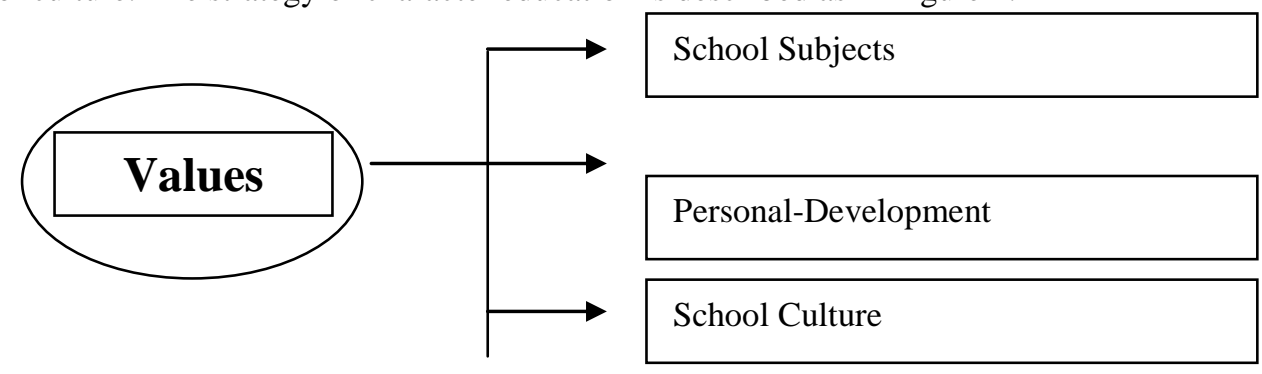

Figure 1.

Strategy of character education

1) Integration in school subjects

Values and character of a nation are developed by integration in each subject. These values are included in the syllabus and lesson plans.

2) Personaldevelopment program

Personal development programs are conducted through value integration into daily school activities.

3) School Culture

Character development in school culture includes exemplification activities by principals, teachers, counselors, administrative staff when communicating with learners.Dharma et.al. (2011: 36) describes three designs of character education in schools are a) integrated in the curriculum contained in all subjects,b) through extracurricular activities, such as scouts and arts, and c) through personal-development activities, such as community service and environmental movement.

\section{Social Caring}

Mather \& Weldon, 2006: 34 says when we are caring,we feel concern for others. Other people's feelings matter to us. We can show our care with our actions by being kind, generous, helpful, and understanding.Stevenson in Young Person's Character Education Handbook (2006: 34) defines caring as feeling of affection for someone or something. While Mc. Elmeel (2002: 1) definescaring as the act of being concerned about another person or situation. It is feeling or acting with compassion, concern, or empathy. Ministry of education (2010: 10) divides caring into two, namely environmental caring and social caring. Caring for the environment is the attitude and actions to prevent damage to the natural environment, and 
develop efforts to repair the natural damage that has occurred. While social caring is defined as attitudes and actions to provide assistance to others and communities in need.

\section{Multicultural based learning}

Multicultural based learning is a learning by integrating multicultural education in the process. It aims to instill social caring and respect among others. To deal with diversity requires a new paradigm, which is called multicultural education paradigm. Multicultural-based education becomes a view in creating concern in the diversity in environments. It will lead students to be more tolerant to diverse conditions of society. Furthermore, it provides affirmation to be appreciative to others and gives awareness that all human beings have equal rights.

According to Banks (in Suryana and Rusdiana, 2015: 211) there are four approaches to integrating multicultural education materials into appropriate school lessons in Indonesia. They are:

a. Contribution approach, which includes introducing heroes and cultural objects from different regions in appropriate learning.

b. Additive approach, which is adding material supplements, concepts, themes, perspectives to the curriculum without changing the structure, objectives and basic characteristics. This approach is usually completed with books and modules without substantially changing the structure. It can be done by equipping classrooms and libraries with learning materials about human life.

c. Transformative approach, which is changing basic assumptions of the curriculum and foster students' basic competencies in perceiving variety of concepts, issues, problems, and perspectives.

d. Social action approach, which aims at educating students to do social criticism, teaches decisionmaking skills to help students become critical towards social change.

The four approaches are used to instill multicultural values into an integrated learning process. Human diversity should encourage individuals to understand differences in race, religion, society, ability, ethnicity, and language. Multicultural education offers solutions to these problems, through the perspective and attitude of dealing with heterogeneity of groups, gender, inter-religious relations, and culture. To implement the four principles and achieve the goal of creating caring individuals, teachers and the school have important roles.

\section{ELT teachers' roles in implementing multicultural-based learning to build students' character of caring}

According to SuryanadanRusdiana (2015:276), teachers' roles in implementing multicultural learning process are building paradigms towards diversity, appreciating language diversity. establishing gender sensitivity, building social care, building anti ethnic- discrimination attitudes, and building anti agediscrimination attitudes. Schools as a formal institution with teachers as agents in education should not only provide education, but it should also build awareness and change the way students perceive diversity. The efforts can be through building anti-discrimination attitude in various aspects of diversity.

Freed (2006: 11) describesthe forms of caring, the elements of which can be implemented in language class activities:

Students help people who are in painful situation.

Students show kindness to family members.

Students show kindness to strangers.

Students resolve a conflict peacefully; and forgive others.

Students offer to help others without being asked to do so.

Students express thank to other and can show my gratitude in a variety of ways.

In language learning, teachers should create activities where students learn how to help others and show caring in many ways, such as asking students how they are doing, which is then followed by the students and having students listen to their friends. Caring can be interpreted as interest, affection, attention to others or something and manifested in attitudes by sharing, receiving, or helping. Caring does not come for granted, but it needs to be known, understood, realized, and manifested in everyday behavior. The task of a teacher in the school is to cultivate the awareness of learners for other students, teachers, and environment. 


\section{CONCLUSION}

Current educational system should build character which is reflected in students' attitude. The process of developing values that form the basis of character education in schools requires a holistic and sustainable process. One way that can be done is through the integration of values on various subjects, including English language. ELT activities and materials should contain values which build of humans with good character. Multicultural approach is seen appropriate to bring the values which arouse students' awareness to possess social caring and respect towards ethnic, race, language, and ability differences.

\section{REFERENCES}

Battistich, V A. (2008). Voices: a practitioner's perspective character education, prevention, and positive youth development. Journal of Research in Character Education, 6, 81-90.

Berkowitz, M. W. \& Simmons, P. (2003). Integrating science education and character education. In Zeidler, D. L. (Ed.), The role of moral reasoning on socioscientific issues and discourse in science education (pp.117-138) [eversion].Netherland: Kluwer Academic Publisher.

Depdiknas. (2003). Undang-Undang RI No 20,Tahun 2003, tentang Sistem Pendidikan Nasional.

Freed, J. (2006). Character empowering with emotional intelligence. Santa Barbara: In Depth Press.

Kesuma, D. et.al.. (2011). Pendidikan karakter kajian teori dan praktik di sekolah. Bandung: Rosda.

Kemdiknas. (2010). Pengembangan pendidikan budaya dan karakter bangsa pedoman sekolah. Jakarta: Pusat Kurikulum.

Lickona, T. (1991). Educating for character: how our school can teach respect and responsibility. New York: Bantam Books.

(2004). Character matters: how to help our children develop good judgment, integrity, and other essential virtues. New York: A Touchstone book.

Mather, A. D. \& Weldon, L. B. (2006). Character building day by day. United States of America: Free Spirit Publishing.

McElmeel, S. L. (2002). Character education (a book guide for teachers, librarians, and parents). United States of America: Teacher Ideas Press.

Muslich M. (2011). Pendidikan karakter menjawab tantangan krisis multidimensional. Jakarta: Bumi Aksara.

Nuh, M. (2 Mei 2011). Tanamkan karakter sejak dini. Swarapendidikan.com.

Stevenson, N. (2006). Young person's character education handbook. United States of America: JIST Publishing.

Yaya, S. \&Rusdiana, H. A. (2015).PendidikanMultikultural. Bandung: PustakaSetia. 